\title{
Investigating effect of Amino Acids Leucine, Valine and Alanine on Alkaline Phosphatase Activity of purified Acetone fractions of Sweet Lemon, Garlic and Onion
}

\author{
Research Article
}

\section{Ramin Tavakoli ${ }^{1}$, Shahdokht Rastegar ${ }^{1}$, Mansoor Khaledi ${ }^{2}$, Ali Nouri ${ }^{3}$, Mostafa Madmoli ${ }^{4}$, Mehran Zamani ${ }^{1}$, Hoshang Roshanmehr ${ }^{{ }^{*}}$}

\section{Student Research Committee, Toxicology Research Center, Department of Clinical Biochemistry, Faculty of Medicine, Ahvaz Jundishapur University of Medical Sciences, Ahvaz, Iran. \\ 2. MS.c. in Medical Microbiology, Department of Microbiology and Immunology, Shahrekord University of Medical Sciences, Shahrekord, Iran. \\ 3. Clinical Biochemistry Research Center, Basic Health Sciences Institute, Shahrekord University of Medical Sciences, Shahrekord, Iran. 4. Emergency Medical Technician, Dezful University of Medical Sciences, Dezful, Iran.}

\begin{abstract}
Alkaline phosphatase enzyme (ALP, ALKP, ALPase, Alk Phos) (EC 3.1.3.1) produced by plants and microbes is presumed to convert organic phosphorus into available pi, which is absorbed by plants. Considering the importance of Alkaline phosphate enzyme and the balance between its function in the development of various diseases by increasing and decreasing the enzyme level by enzyme activating and regulating compounds, including amino acids and ions, which act as coenzyme and cofactor for the enzyme Can be a major role in Disease improvement. This study aims to comparatively investigate the inhibiting effect of the three Amino Acid as well as Alanine, Leucine and valine on Alkaline phosphatase was which extracted from Sweet Lemon (Citrus limon (L.) Osbeck), Garlic (Allium sativum L.) and Onion (Allium cepa L.). In this study, Leucine, Alanine and Valine amino acids showed strong inhibitory effects $23 \%, 26 \%$ and $34 \%$ respectively activity of Alkaline phosphatase obtained saline extract of plants Sweet Lemon, Garlic and Onion.
\end{abstract}

Keywords: Alkaline phosphatase, Leucine, Alanine, Valine.

\section{Introduction}

Alkaline phosphatase (EC 3.1.3.1) exists in animates (animals, plants, microorganisms and yeasts) $(1,2)$. This enzyme is one of the most ubiquitous enzymes and has been found in yeasts, molds and seeds of some plants, fruits and in many animal tissues such as bovine brain, kidney, liver, spleen, erythrocytes, bones, placenta, hepatocytes and blood plasma $(3,4)$. These phosphatases catalyze hydrolysis reactions of a variety of orthophosphate esters as well as transphosphorylation reactions in acid medium. It has been characterized and purified from various sources, such as; chickpea seeds $(5,6)$, pea nuclei (7), bovine brain (8), Medicago truncatula roots (9), mode rarely thermophilic bacterial strain (10), yeast Yarrowia lipolytica (11), bovine liver (12) and banana fruit (13). Because this enzyme is a group of enzymes that can catalyze hydrolysis reactions of a variety of orthophosphate esters in acid medium so

\section{*Corresponding Author:}

Hoshang Roshanmehr,

Student Research Committee, Toxicology Research

Center, Department of Clinical Biochemistry,

Faculty of Medicine, Ahvaz Jundishapur University of Medical Sciences, Ahvaz, Iran.

Email id: roshanmehrh132@yahoo.com it can release phosphate from bones such as tooth or any other bone structure. Consequently, it causes bone disease. Due to important role of enzymes in regulating metabolism and factors affecting its activity can said investigate effective factors in the activity of enzymes as amino acids and ions are necessary to study. The role of amino acids in activating and inhibiting enzymes is that when amino acid concentrations increase in enzymatic environment enzymes, these amino acids can show hydrophobic reaction with amino acids of the apoenzyme and as a result the active site of the enzyme undergoes changes that affect the activity of enzymes with respect to these statements and causes the enzyme's main activity to be altered and inhibited (12-15). The aim of this study was to evaluate the effects of leucine, valine and Alanine amino acids on acetone fraction Alkaline phosphatase enzyme obtained from saline extract of Sweet Lemon, Garlic and Onion plants.

\section{Materials and Methods \\ Chemicals}

Sodium azide (Reidel, Germany); Ammonium persulphate (May and Baker Ltd., England); Ethylenediamine tetra acetic acid (E. Merck, Germany), Butanol, Acetone Leucine, Valine, Alanine and dialysis bag were obtained from Sigma Aldrich. 
Partial purification of alkaline phosphatase and effect of amino acids on enzyme

We obtained saline extract of plants Sweet Lemon (Citrus limon (L.) Osbeck), Garlic (Allium sativum L.) and Onion (Allium cepa L.) as first step of partial purification of enzyme. The protein homogenate of antecedently step was mixed with cold 1- butanol and butanol separately. After centrifugation, the resulting precipitate collected and was extracted with $100 \mathrm{ml}$ saline. Since ammonium sulfate (30-80\%) precipitates, the obtained precipitate was dissolved in minimum amount of saline and dialyzed against the same till free of ammonium sulfate. The enzyme was incubated with amino acids $(30 \mathrm{mM})$ in separate tubes for 1 hour separately, followed by determination of enzyme activity The protein concentrations and sugar were determined by the method of Lowry (5), (14-16).

\section{Enzymatic activity assay}

The Alkaline Phosphatase activity was detected using p-nitrophenyl phosphate disodium salt as substrate. In brief, $100 \mu \mathrm{L}$ of the enzyme containing 10 $\mu \mathrm{g}$ proteins was added to a tube. $200 \mu \mathrm{L}$ of the substrate (2mM p- nitrophenyl phosphate disodium salt) and 200 $\mathrm{mM}$ of citrate buffer $(\mathrm{pH} 4.6,0.1 \mathrm{M})$ were added. Concentrations of each of the compounds of interest are prepared and for each concentration of a test tube, control is considered for all concentrations. To each test tube, $2 \mathrm{ml}$ of saline, $1 \mathrm{ml}$ of buffer with $4.5 \mathrm{pH} 0.2 \mathrm{cc}$ Sample containing enzyme and $0.2 \mathrm{cc}$ amino acids are added and all tubes are placed in laboratory conditions for 5 hours. Then to all of them $0.2 \mathrm{cc}$ of the solution 1 $\mathrm{mm}$ substrate added and after 2 hours to all tubes added $1 \mathrm{cc} \mathrm{NaOH} 10 \%$. The light absorption is read at $405 \mathrm{~nm}$ wavelengths. It is repeated 3 times for assurance as a result of the test. The p-nitrophenol release was measured by its absorbance at $405 \mathrm{~nm}(5,17)$.

\section{Ethical principles}

This project was approved by the code of ethics of ajums IR.AJUMS. REC.1396.397 in student research committee of Ahvaz Jundishapur University of Medical Sciences.

\section{Statistical analyses}

Statistical analysis was performed with SPSS version 18. Data was analyzed using descriptive statistical methods including mean and standard deviation, and compared by one-way analysis of variance (ANOVA) followed by Tukey's post hoc test. The significant level was less than $0.05(\mathrm{P}<0.05)$.

\section{Results \\ Isolation of Alkaline Phosphatase}

We had partially purified alkaline phosphatase from plants extract of Sweet Lemon (Citrus limon (L.) Osbeck), Garlic (Allium sativum L.) and Onion (Allium cepa L.) in Table 1 . The alkaline phosphatase activity $(\mathrm{U} / \mathrm{ml})$, Protein concentration $(\mathrm{mg} / \mathrm{ml})$ and Specific activity (U/mg) was shown at Table 1 . The enzyme was purified and the final specific activities of Sweet Lemon, Garlic and Onion were 48.2, 73.42 and 76/25 $\mathrm{U} / \mathrm{mg}$ respectively. Then enzyme incubation with Concentration of $30 \mathrm{mM}$ various amino acid in separate tubes for 5 hours, followed by determination of enzyme activity was achieved. The results are showed that Leucine, Alanine and valine had strong inhibitory effects on enzymatic activity. The inhibiting effect of the three amino acids Alanine, Leucine and Valine on the activity of alkaline phosphatase was determined. All three tested amino acid inhibited the activity of alkaline phosphatases. In alkaline phosphatase activity of Lemon, Alanine showed the most inhibiting value $14 / 71 \%$ and followed by Valine $9.48 \%$ but leucine increased enzyme activity to $4.07 \%$. In alkaline phosphatase activity from Onion, Valine showed the most inhibiting value $(62.56 \%)$, followed by Alanine and leucine have inhibition 53.56 and 53.45 respectively also in alkaline phosphatase activity from Garlic, Alanine showed the most inhibiting value (49.95\%), followed by Valine and Lucien have inhibition 26.24 and 22.15 respectively. The results also showed in Figures 1, 2 and 3.

Table 1: Partial Purification steps of alkaline phosphatase of plants, Sweet Lemon (Citrus limon (L.) Osbeck), Garlic (Allium sativum L.) and Onion (Allium cepa L.).

\begin{tabular}{|l|l|l|l|l|}
\hline Plant & Step & $\begin{array}{l}\text { alkaline phosphates } \\
\text { activity } \\
\text { U/ml }\end{array}$ & $\begin{array}{l}\text { Protein } \\
\text { concentration } \\
\mathbf{m g} / \mathbf{m l}\end{array}$ & $\begin{array}{l}\text { Specific activity } \\
\text { U/mg }\end{array}$ \\
\hline \multirow{2}{*}{$\begin{array}{l}\text { Sweet } \\
\text { Lemon }\end{array}$} & Acetone extract & 29.52 & 1.41 & 20.9 \\
\cline { 2 - 5 } & Ammonium sulphate extract & 17.96 & 0.374 & 48.2 \\
\hline \multirow{2}{*}{ Garlic } & Acetone extract & 23.94 & 1.24 & 19.3 \\
\cline { 2 - 5 } & Ammonium sulphate extract & 25.7 & 0.35 & 73.42 \\
\hline \multirow{2}{*}{ Onion } & Acetone extract & 24.32 & 0.52 & $46 / 7$ \\
\cline { 2 - 5 } & Ammonium sulphate extract & 12.2 & 0.16 & $76 / 25$ \\
\hline
\end{tabular}


Fig. 1: Effect of Valine on alkaline phosphatase activity of Lemon, Onion and Garlic.

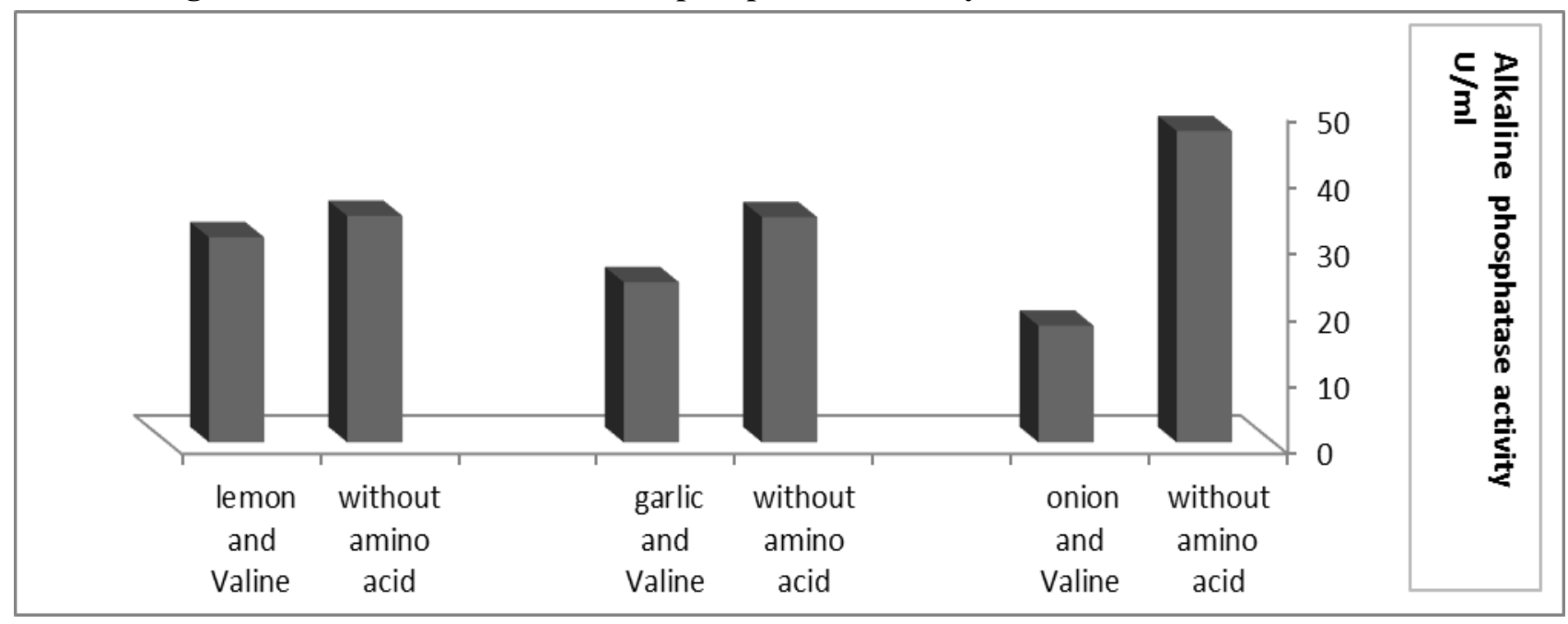

Fig. 2: Effect of Leucine on alkaline phosphatase activity of Lemon, Onion and Garlic.

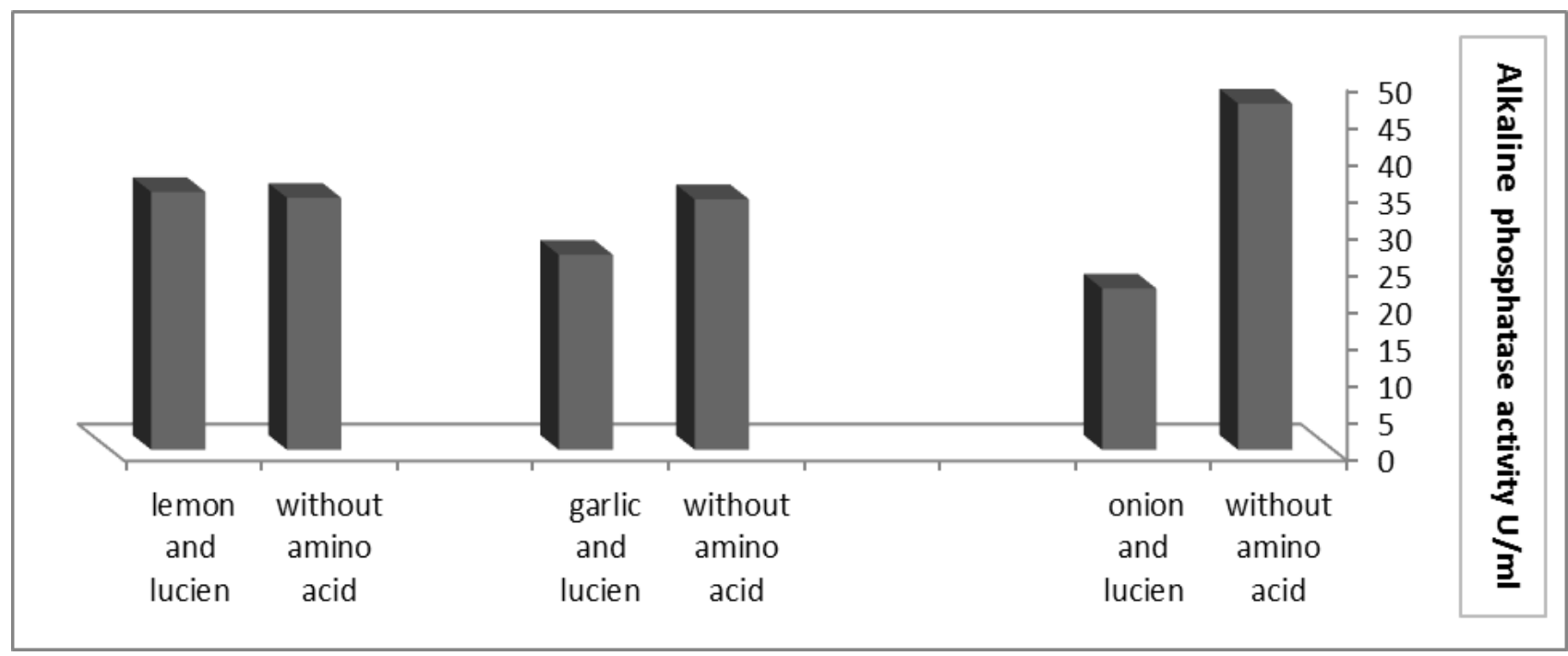

Fig. 3: Effect of Alanine on alkaline phosphatase activity of Lemon, Onion and Garlic.

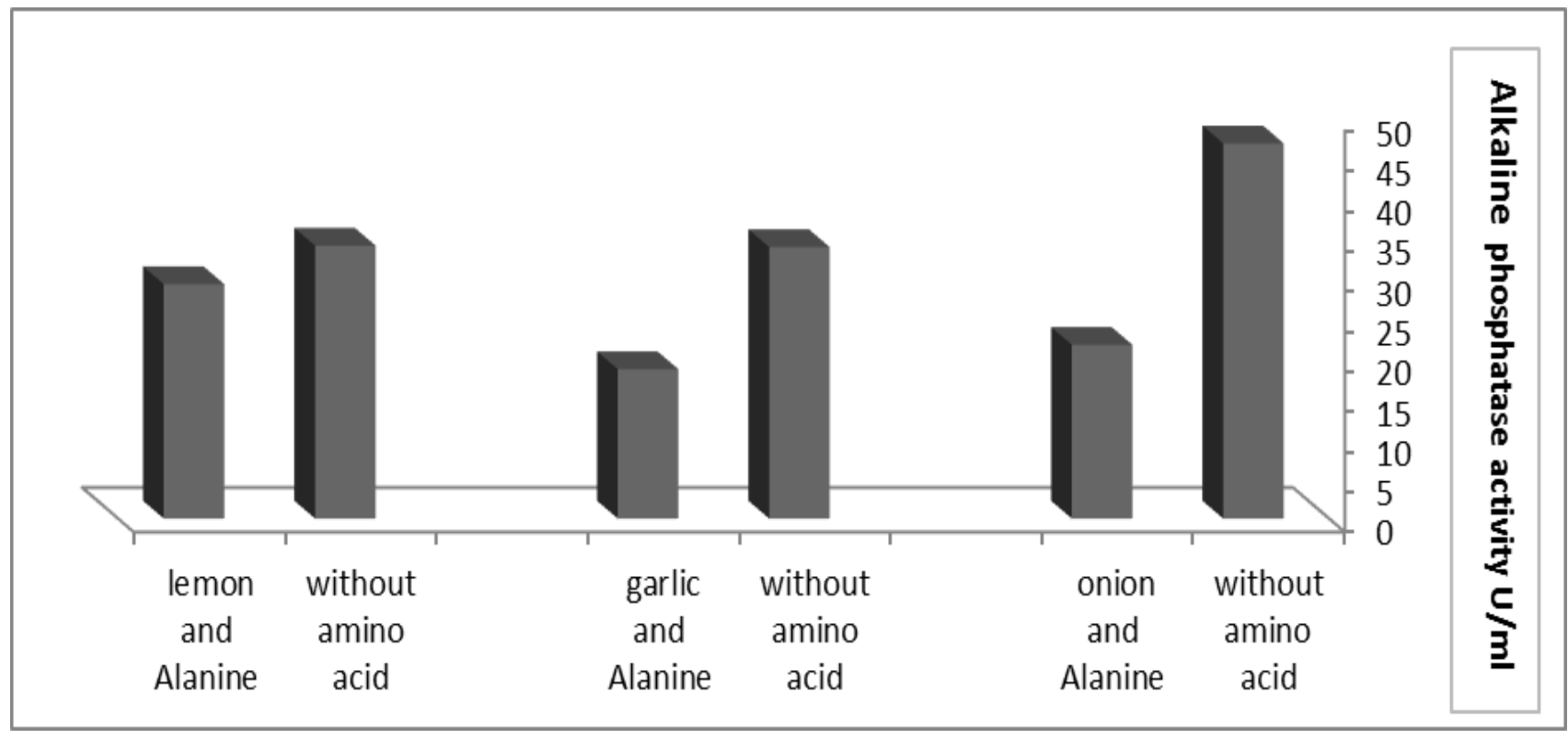




\section{Discussion}

The measurement of alkaline phosphatase enzyme is recommended as a routine screening test for the diagnosis of various diseases, including cholestasis, biliary obstruction, obstructive jaundice, cysts and liver abscesses and bone marrow metastases (18). This study examines the effect of amino acids of Leucine, Valine and Alanine on alkaline phosphatase activity. The alkaline phosphatase purified of plants Sweet Lemon (Citrus limon (L.) Osbeck), Garlic (Allium sativum L.) and Onion (Allium cepa L.) by ammonium sulphate precipitation and Dialysis bag. Then it was affected by amino acids. The results show the enzyme activity was inhibited by the polyamines (amino acids) as Valine, Alanine and Leucine. Considering that the increase of this enzyme in the body is associated with the onset of mitosis, cholestasis, biliary obstruction, obstructive jaundice, cysts and liver abscesses, bone marrow metastases, germinal vesicle fracture also increasing the activity of the enzyme as a biochemical marker for inadaptation to hepatocellular factors $(18,19,20)$. In addition, decreasing activity alkaline phosphatase enzyme by removing the phosphate from the pathways of the glycogen metabolism pathway leads to a change in the activity of these enzymes and can make sure that the metabolism of glycogen is threatened and lead to liver disease. For this reason, we decided to study the effect of amino acids of valine, Alanine, Leucine on alkaline phosphatase activity. So, if enzyme activity decreased under effect of amino acids, the amino acids acts as inactivator of the glycogen metabolism pathway and cholestasis, bone marrow metastases and germinal vesicle fracture $(21,22,23)$. In this study, the inhibitory effect of valine was found to be higher than the other. It can be concluded that valine inactivates the alkaline phosphatase enzyme in the mentioned diseases. Therefore, in the future, the active ingredient of the Alkaline phosphatase inhibitor Valine can be given as a medicine, and it can be given to the patient during the treatment of the diseases under the supervision of the physician, thereby increasing the Control of activity of the Alkaline phosphatase in the cell and serum.

\section{Conclusion}

We conclude that during the treatment of diseases, the amount of activity of the alkaline phosphatase enzyme should be monitored. Thus, the amino acids as activators or inhibitors metabolic pathway are necessary for Human. Also Leucine, Alanine and Valine can be used as inhibitors alkaline phosphatase activity against its high level in patients.

\section{Acknowledgements}

This project was approved by the code of ethics of ajums IR. AJUMS. REC.1396.397 in student research committee of Ahvaz Jundishapur University of Medical Sciences. We are very thanks Students Research Committees, Ahvaz Jundishapur University of
Medical Sciences for grant of this work and we would like to express our gratitude to those who have helped us in Clinical Biochemistry Research Center of Shahrekord University of Medical Sciences, Shahrekord, Iran.

\section{Conflict of interest}

There are no conflicts of interest in this study.

\section{References}

1. Cedro Fernandes E, Mauro Granjeiro J, Mikio Taga E, Meyer-Fernandes JR, Aoyama H. Phosphatase activity characterization on the surface of intact bloodstream forms of Trypanosoma brucei. FEMS Microbiol Lett., (2003); 220(2):197- 206.

2. Demir Y, Yildirim S, Alayli A, Demir N. Characterization and purification of acid phosphatase from ancient human bone. Prep Biochem Biotechnol., (2003); 33(4):311- 20

3. Hiroyama M, Takenawa T. Purification and characterization of a lysophosphatidic acid-specific phosphatase from bovine brain.,Biochem J., (1998); 336:483- 9

4. Stromhaug PE, Berg TO, Fengsrud M, Seglen PO. Purification and characterization of at utophagosomes from rat hepatocytes. Biochem J., (1998);335:217- 24

5. Mohammad Aberomand and Shobhana V. Bhide, purification and partial characterization of a novel acid phosphatase from Chickpea Seeds, Biochemical and Cellular Archives, (2007); 7 (2): 171-176. ISSN 0972- 5075.

6. Mohammad Aberomand, Alireza Khirolah and Sarah Aberomand (2009) pH dependant acid phosphatase activity in some plants, Biochem. Cell. Arch. 9, 163-164.

7. Guo Y L and Roux S J (1995) Partial purification and characterization of an enzyme from pea nuclei with protein tyrosine phosphatase activity. Plant Physiol. 107, 167-75.

8. Fujimoto S, Gotoh H, Ohbayashi T, Yazaki H and Ohara A (1993) Purification and characterization of zinc-dependent acid phosphatase from bovine brain. Biol. Pharm. Bull. 745-50.

9. Liu H, Trieu A T, Blaylock L A and Harrison M J (1998) Cloning and characterization of two phosphate transporters from Medicago truncatula roots: regulation in response to phosphate and to colonization by arbuscular mycorrhizal (AM) fungi. Mol. Plant Microbe Interact. 11, 14-22.

10. Sugio T, Oda K, Matsumoto K, Takai M, Wakasa S and Kamimura K (1998) Purification and characterization of sulfur reductase from a moderately thermophilic bacterial strain, TI-1, that oxidizesm iron. Biosci. Biotechnol. Biochem. 62, 705-9.

11. Jolivet P, Queiroz-Claret C, Bergeron E and 
Meunier J C (1998) Characterization of an exocellular protein phosphatase with dual substrate specificity from the yeast Yarrowia lipolytica. Int. J. Biochem. Cell. Biol. 30, 78396.

12. Tsuda J, Kimura T, Tanino H, Shimohama $\mathrm{S}$ and Fujimoto S (1998) Characterization of high- and low-molecular weight zincdependent acid phosphatases in bovine liver. Biol. Pharm. Bull. 21, 1218-21.

13. Turner W L and Plaxton W C (2001) Purification and characterization of banana fruit acid phosphatase. Planta 214, 243-249.

14. Mohammad Aberomand and Soltanzadeh M (2006) Purification and Characterization of Psedocholinesterase from sheep Liver, Biochem. Cell. Arch. 6, 253-256.

15. Mohammad Aberomand and Shabhana V. Bhide (2007) Purification and Characterization of alpha mannosidase from Chickpea seeds, Biochem. Cell. Arch. 7, 32- 40.

16. Mohammad aberomand et al (2008) Effect of metal ions, Determination of Molecular weight and chemical modification of novel chickpea seeds, acid phosphatase. Biochem. Cell. Arch.8, .19-20.

17. Mohammad Aberomand Total protein in leaves of Orange (Citrus Sinensis), Onion (Allium cepa L.), Garlic (Allium Sativum) and Sweet Lemon( Citrum
Lemon), Biochemical and Cellular Archives. (2009): 9(1): 97-98.

18. Fotiou K. Vaiopoulos G. Lilakos K. Giannopoulos A. Mandalenaki K. Marinos G. Koritsiadis G. Sourdis J. Konstantinidou E. Konstantopoulos K. Serum ceruloplasmin as a marker in prostate cancer. Minerva Urol Nefrol. (2007)

19. Taira A. Merrick G. Wallner K. Dattoli M. Reviving the acid phosphatase test for prostate cancer. Oncology (Williston Park) (2007)

20. Angulo-Valadez CE. Cepeda-Palacios R. Ascencio F. Jacquiet P. Dorchies P. Romero MJ. Khelifa RM. Proteolytic activity in salivary gland products of sheep bot flies (Oestrus ovis) larvae. Vet Parasitol. (2007).

21. Nayyar B. Rishi P. Shukla G. Plasmodium berghei induced biochemical alterations in pregnant mice. Nepal Med Coll J. (2007).

22. Saftig P, Hartmann D, Lullmann-Rauch R, Wolff J, et al. Mice deficient in lysosomal acid phosphatase develop lysosomal storage in the kidney and central nervous system. J. Biol. Chem.1997; 272: 1862818635.

23. Duff S. M.G, Sarath G, Plaxton, W. C. [The role of acid phosphatase in plant phosphorus metabolism]. Physiologia Plantarum.2006; 90, 791-800. 